\title{
APPROVAL OF PURCHASE PRICE IN SALE OF AIRLINE PROPERTIES UNDER THE CIVIL AERONAUTICS ACT
}

The Civil Aeronautics Board, in a recent decision approving the sale of an airlines route by one air carrier to another, has reaffirmed a policy which may have important effects on the future of economic airline regulation. ${ }^{\text {I }}$ Western Air Lines, a carrier operating primarily in the region west of the Rocky Mountains, had in recent years extended its activities eastward by the establishment of a route from Los Angeles to Denver and the acquisition of control of a subsidiary operating as far east as Minneapolis and St. Paul. The Denver-Los Angeles route proved profitable to Western in 1946 but, early in 1947 , the company found itself in serious financial difficulties in its other operations and it determined to abandon its transcontinental ambitions. The prospect of future profitable operation of the Denver-Los Angeles route by Western being extremely poor, ${ }^{2}$ it was decided that the route should be sold. In March, I947 an agreement was negotiated by which Western was to transfer its certificate of public convenience and necessity for the route to United Air Lines, along with the planes and other physical properties used by Western on the route. The purchase price agreed upon was $\$ 3,750,000$, although the equipment and other tangible items involved were valued at slightly over $\$ 2,000,000$. As required by statute, the agreement was submitted to the Civil Aeronautics Board for approval.

The five members of the Board all agreed that it was in the public interest that Western be allowed to abandon its Denver-Los Angeles route and that the route be transferred to United, into whose system it logically fitted. The Board also agreed that, for rate-making purposes, the route could be valued at no more than the fair value of the physical equipment used in its operation. The Board split, four members to one, however, on whether United should be allowed to pay the excess of some $\$ 1,750,000$ over the value of the equipment.

The majority voted to approve the purchase price. They asserted that the value put on the route was the result of arms-length bargaining, and that the Board could not realistically overlook the fact that the route might be worth more to United than the allowable rate base investment figure. To make sure that only the value of the equipment would ever be used for rate-making purposes, United was ordered to charge the amount exceeding the fairvalue of the

\footnotetext{
× Western-United, Acquisition of Air Carrier Property, C.A.B. Docket No. 2839 (Aug., 1947).

2 A substantial portion of Western's traffic on the route was derived from United Air Lines' lack of an entry into Los Angeles. United's passengers from east of Denver who wished to go to Los Angeles had to transfer to Western at Denver. It became clear early in 1947 , however, that the Board would probably permit direct access to Ios Angeles by United, in which case Western would be thrown back on the route's local traffic, which was not large enough to sustain profitable operations. Just prior to commencing hearings on the instant case the Board did, in fact, give United permission to fly to Los Angeles direct. Transcontinental \& Western Air, Consolidation of Routes, C.A.B. Docket No. 2I42 (May, I947).
} 
properties to its surplus account so that the stockholders would immediately be assessed for it. ${ }^{3}$

Chairman Landis, dissenting, doubted that any strong resolutions or accounting techniques could prevent the excessive price from eventually burdening the public. He pointed out that the payment by United for intangibles was nothing more than a capitalization of expected future earnings in excess of a fair return on the rate base and he asserted that for the Board to recognize such a value would be a betrayal of its responsibilities to the public.

The Civil Aeronautics Board has, since its inception in 1938 , been concerned with a dynamic and growing industry whose ultimate place in the economy cannot yet be foreseen. This atmosphere of uncertainty and growth has dominated the problems coming before the Board, most of which have dealt with airline expansion and development; it perhaps also explains the relative lack of concern and understanding shown by the majority of the Board in the Western-United case for the problem which must eventually be faced when the airlines reach a level of stability, namely, the minimization of the cost of air transportation to the public.

The Civil Aeronautics Act, ${ }^{4}$ under which the Board operates, was passed at a time when the airlines were going through a period of severe depression, ${ }^{5}$ due primarily to their inability to conduct profitable passenger-carrying operations, and to the lack of a workable arrangement with the government for the transportation of mail. ${ }^{6}$ The statute placed the industry under the control of the regulatory agency, which was given the power to set rates, ${ }^{7}$ to issue route certificates, ${ }^{8}$ to require uniform accounting procedures, ${ }^{9}$ and to approve or disapprove of mergers and combinations. ${ }^{\text {to }}$ In return, the airlines were assured a measure of stability in the then-existing route pattern. Most important, the agency was directed, through the disbursement of varying mail-carrying rates, to insure that well-managed and essential airlines received revenues adequate for the development and continuation of efficient operations. ${ }^{\text {II }}$ This authority to grant sub-

${ }^{3}$ Shortly after the decision in this case the Board issued a supplementary order requiring United to charge the excess in the price to "Other Intangible Assets," since United's surplus account was no longer large enough to absorb the amount. C.A.B. Order No. E-786 (Sept., x947).

${ }_{4}^{4}{ }^{2}$ Stat. 977 (1938), 49 U.S.C.A. $\$ 401$ (Supp., 1946).

5 It was estimated in 1937 that of some $\$$ I $20,000,000$ invested in the airlines, more than $\$ 60,000,000$ had been lost. Hearings before the House Committee on Interstate and Foreign Commerce on H.R. 9738, March 1937 , at 298.

${ }^{6}$ See The Economic Regulation of Air Transport, 5 Univ. Chi. L. Rev. 47x (r938).

${ }^{7} 49$ U.S.C.A. $\$ \$ 483,484,486$ (Supp., I946).

8 Ibid., at $\$ 48$ r. $\quad 9$ Ibid., at $\$ 487$. $\quad{ }^{20} \mathrm{Ibid}$., at $\$ 488$.

II "In fixing and determining fair and reasonable rates of compensation [for transportation of maill, the Board, considering the conditions peculiar to transportation by aircraft and to the particular air carrier or class of air carriers, may fix different rates for different air carriers..... 
sidies, ${ }^{12}$ carrying with it the responsibility for the growth of the nation's air transportation system, has dominated the Board's thinking even up to the present time, when most of the important domestic air carriers no longer need and are not receiving direct financial aid.

The important decisions made by the Board in its early years are those in which it established subsidy mail rates for the airlines. Rates were set for each carrier to provide revenue which would fill the gap between the income from passenger and freight operations and necessary operating expenses, and also to afford some margin of profit. ${ }^{\mathrm{I3}}$ The Board did not then and has not since developed any definite criteria for the determination of how much profit an airline should be allowed. It has at times used a rate of return standard based on a rate base of the original cost less depreciation of physical equipment plus a provision for working capital, ${ }^{14}$ and presumably that system will be used in the future should close control of profits be attempted. Since the early years of World War II, however, the rate of return problem has been largely academic, since the Board has exercised almost no control over profits. The major carriers have long since become self-sufficient on the basis of their passenger operations and the Board has established for them "service" mail rates designed only to cover their mail-carrying costs. ${ }^{15}$ At the same time the Board has made no at-

In determining the rate in each case, the Board shall take into consideration, among other factors .... the need for each such carrier for compensation for the transportation of mail sufficient to insure the performance of such service, and, together with all other revenue of the air carrier, to enable such air carrier under honest, economical, and efficient management, to maintain and continue the development of air transportation to the extent and of the character and quality required for the commerce of the United States, the Postal Service, and the national defense." Ibid., at $\$ 486(b)$.

s2 There has been some disagreement over the definition of "subsidy" in relation to air mail payments. Spencer, Air Mail Payment and the Government 303-I2 (194I). Airline management has argued that a subsidy exists only when mail payments to the carriers exceed the air mail revenues of the Post Office Department. A more accurate description would seem to be that there is a subsidy whenever payments to the carriers exceed their mail-carrying costs plus a reasonable profit on the operation. See Federal Coordinator of Transportation, I Public Aids to Transportation 130 (I940). A constant indirect subsidy is also provided through government maintenance of airways and air navigation facilities.

${ }_{3}$ See cases listed in Spencer, op. cit. supra note 12, at 255; see also Burt and Highsaw, Regulation of Rates in Air Transportation, 7 La. L. Rev. 1,378 (1946).

14 The Board has avoided the use of a standardized rate of return and instead has made such rates variable, as an incentive to efficient management. Colonial Airlines, Mail Rates, 4 C.A.B. 7 I (1942); American Airlines, Mail Rates, 3 C.A.B. 323 (I942). Only during the war years, when expansion of facilities was restricted and the Board assumed that all carriers were devoting themselves to the war effort, were similar rates of return set for all carriers. Northeast Airlines, Mail Rates, 4 C.A.B. 181, r89 (1943); Pan American-Grace Airways, Mail Rates, 3 C.A.B. 550, 589 (1942).

${ }^{25}$ Eastern Air Lines, Mail Rates, 3 C.A.B. 733 (1942); American Airlines, Mail Rates, 3 C.A.B. 770 (1942); United Air Lines, Mail Rates, 4 C.A.B. 128 (1943); Transcontinental \& Western Air, Mail Rates, 4 C.A.B. I39 (I943). It is indicative of the Board's general approach that even in these cases a mail rate was set which allowed a generous margin over mailcarrying costs as a profit on the operation and as a reserve against future contingencies. See the dissenting opinions of Member Branch in all four cases above, where he points out that the rate set amounts to the giving of a subsidy to carriers which do not need it. 
tempt to regulate passenger rates but has left them to the forces of competition, ${ }^{26}$ presumably because the continued uncertainty and unprediotability of the industry would make close control impractical and inadvisable. Under this liberal regulatory policy it has at times been possible for the major carriers to make profits considerably in excess of the fair return which the Board might allow if it were exercising strict regulation of profits.

Under Sections 40I, 408, and 412 of the Act, the Board is given the authority to approve or disapprove of transfers of property or certificates between airlines, approval to depend on the vague standard of the "public interest." ${ }^{17}$ The first important acquisition case to come before the Board arose in I940, when Marquette Airlines proposed to sell all its equipment and certificates to T.W.A. The equipment to be transferred was valued at only $\$ 30, \infty 00$, but the purchase price was to be $\$ 470,000$. The Board at first refused to approve the agreement, pointing out that almost the entire price was being paid for operating rights, and that since certificates were matters of free public grant they should not be treated as "speculative securities." applied for approval of the same agreement, with the consideration reduced to $\$ 3$ I3,000. Although the change had obviously not eliminated the defects condemned in its first decision, the Board reversed itself and approved the sale. ${ }^{39}$. The Board's position now was that airline operating rights have an exchange value which it could not ignore; that, although the prices paid for such intangibles would have no bearing on a carrier's investment rate base, the Board still would approve the transaction. After the second Marquette decision the Board did not have to face squarely the problem of certificate transfers until the Western-United agreement came up for approval. ${ }^{20}$

\section{II}

The critical question posed by the Western-United transaction was whether an airline route can be sold by one carrier to another at a price in excess of the allowable investment rate base without an added burden eventually being passed on to the public. If the buying carrier were allowed to include the full amount of the purchase price in its rate base the effect on the public would be clear; the majority of the Board, however, emphatically stated that it would

${ }^{16}$ Burt and Highsaw, op. cit. supra note $I_{3}$, at 7 .

${ }^{17} 49$ U.S.C.A. $\$ \S 48 \mathrm{I}(\mathrm{i}), 488(\mathrm{a})(2), 492$ (b) (Supp., I946).

${ }^{18}$ Acquisition of Marquette by T.W.A., 2 C.A.B. I (1940).

1 Acquisition of Marquette by T.W.A., Supplemental Opinion, 2 C.A.B. 409 (I940).

${ }^{20}$ The Board disapproved two proposed transactions which appeared to be unwise ventures on the part of the purchasing carriers. National-Caribbean-Atlantic Control Case, 6 C.A.B. 67x (I946); Braniff Airways, Acquisition of Aerovias Braniff, 6 C.A.B. 947 (1946). In others, the purchase price seemed to bear a reasonable relation to the value of the physical property. Wien Alaska Airlines, Acquisition of Mirow Air Service, 3 C.A.B. 207 (194I); Western Air Lines, Acquisition of Inland Air Lines, 4 C.A.B. 654 (I944); Acquisition of Mayflower Air lines by Northeast Airlines, 6 C.A.B. 139 (I944); Acquisition of Ferguson Airways by Wien Alaska Airlines, C.A.B. Docket No. 2228 (Jan., 1947). 
never allow the rate base to be enlarged by reason of the price paid. The public can be impressed with an added burden, however, even though the rate base figure remains inviolate. If, because of the excess expenditure, the Board is forced in its regulation to allow the buying carrier a higher rate of return than it otherwise would, or must dispense subsidies in periods of losses sooner than otherwise, the effect on the public will be comparable to that which would have arisen from an immediate enlargement of the rate base.

The public is at present paying the passenger rates on the Denver-Los Angeles route which have provided high profits for Western and on which United is depending for high profits in the future. If such profits continue, United, besides receiving a fair return on the $\$ 2, \infty 00, \infty 00$ invested, may in time recover the full amount of $\$ \mathrm{r}, 750,000$ which it has paid out for operating rights. At that moment it will stand in the same position as if it had just been given the certificate at no cost. The only effect of the transaction will have been that the excess profits for the first period of United's operation will have gone to Western by inclusion in the purchase price. It might in that situation be said that the public had received no added burden by reason of the payment of the excessive price; the determination of the majority of the Board to protect the rate base figure, however, will not have contributed to that result. The public will have been spared an added burden only because the Board has allowed the present burden of high passenger rates to continue long enough for United to recover its investment in operating rights.

The principal difficulty in the majority's position lies in the possibility that United will not make the high profits anticipated and will find itself in the position of having invested $\$ 3,75^{\circ}, 000$ in a route that will provide a return adequate only for an investment of $\$ 2,000,000$. If a general decline in airline traffic should thus diminish the carrier's profits, it seems impossible that the Board could isolate the public from the results of United's having wasted $\$ I, 750,000$ of its assets. With its surplus depleted, United's position in seeking capital would be weakened and it would need extra revenue with which to attract investors. Moreover, having wasted part of its reserve, United would be less able to absorb temporary operating losses and would have to come to the Board for subsidies sooner than it otherwise would. In neither situation could the Board, charged as it is with the well-being of the airlines, refuse to allow United the subsidy revenues required to continue efficient operations. The Board might be able to retain a superficial appearance of consistency by affording the required relief without a specific increase of the rate base. The allowance of a higher rate of return, however, would have the same burdensome effect on the public. Similar results will follow if, before United has recovered its excess investment in the route, the Board adopts a policy of close rate control. The Board would have to allow a higher rate of return than that which would have been considered adequate if United had not spent the extra $\$ 1,750,000$. No matter how it is handled the public will pay the bill. 
The effect of the Board's ruling, in short, is to guarantee the continuation of the burden now borne by the public which is contributing to the high profits made on the Denver-Los Angeles route. That guarantee covers not only the possibility of a decline in passenger revenues but it will be equally effective against efforts by the Board itself to restrict profits to a fair return on the value of the physical property.

The fact is, of course, that airline prospects for business are good, and the Board has given no indication of plans to establish effective rate control in the near future. It may well be that in this particular situation United's investment in operating rights is safe. In an industry as unpredictable as air transportation, however, it is unwise for the regulatory agency to count on a carrier's continued prosperity. ${ }^{2 x}$ It is likewise unwise for an agency to permit a transaction which may tie its own hands should it attempt to limit the cost of airlines service to the public. The Board in the Western-United case had an excellent opportunity to establish a well-defined policy forbidding the capitalization of future excessive earnings and thus guard against an inflation in airlines investment.

The majority of the Board pointed out that there are precedents in the decisions of other regulatory agencies which seem to support its treatment of the Western-United transaction. The Interstate Commerce Commission has permitted the transfer of motor carrier routes at prices above the value of the tangible property involved, and has required that the excess portion of the price be charged against surplus or be amortized against income over a period of years..2 The Federal Power Commission has permitted the sale of power properties with similar accounting requirements. ${ }^{23}$ The motor carrier and power industries, however, present problems which are radically different from those of the airlines. Neither the Federal Power Commission nor the Interstate Commerce Commission is charged with the encouragement and development through subsidization of the industries they regulate. The Federal Power Commission does not guarantee a minimum rate of return and it can enforce its rate base without regard for the actions of the individual companies. ${ }^{24}$ In the highly competitive motor

${ }^{2}$ On Nov. 24, 1947, United Air Lines filed a petition with the Board requesting an increase in mail compensation from the old rate of $\$ .45$ a ton mile to $\$ 2.26$ a ton mile for 1947 (retroactive) and \$r.25 for 1948 . Besides citing increases in its operating costs, United referred to current losses caused by the suspension of DC- 6 service and argued that air carriers should be "provided" with an adequate return on their invested capital. Chicago Daily Tribune, p. 37, col. 7 (Nov. 25, 1947).

2 Skeel-Purchase-Jess Kuhns and Grays Harbor Lines, 40 M.C.C. 3 I8 (I945); Mason \& Dixon Lines-Purchase-Goggins and Cox, 36 M.C.C. 475 (I94); Buckingham Transportation Co.-Purchase-Casey, 25 M.C.C. 667 (I939).

${ }^{23}$ Virginia Electric \& Power Co., 4 F.P.C. 5I (I944); Empire District Electric Co., 4 F.P.C. 665 (1944).

${ }^{24}$ See the cases in which the Commission has compelled power companies to eliminate items from their capital accounts which represent values previously placed on properties above their original cost. California Oregon Power Co. v. Federal Power Commission, I5o F. $2 d 25$ (C.C.A. 9th, 1945); Pacific Power \& Light Co. v. Federal Power Commission, I4I F. 2d 602 
carrier industry, on the other hand, the issue in the principal rate cases has been that of low rates rather than high rates which burden the public. ${ }^{25}$ The wording of the motor carrier decisions, moreover, indicates that the Interstate Commerce Commission's accounting requirements in acquisitions are designed not to protect a rate base, but merely as a general precaution against an unhealthy inflation of book values by the writing in of speculative intangible assets. ${ }^{26}$

The facts of the Western-United situation make possible an argument which may have some appeal for those who wish to leave the airlines completely free to trade routes among themselves. Western Air Lines is a "need" carrier receiving subsidy mail payments from the Board. It might be argued that any burden placed on the public by United's payment of the excessive purchase price will be balanced by an equal benefit to the public through Western's receiving extra revenue which otherwise would have to be provided through subsidies. Although such a balance might work out, it would be impossible to measure; certainly the Board could not rely on it. In the Western-United situation it would amount to a tax on the users of the Denver-Los Angeles route in favor of the rest of the public which contributes to the subsidies going to Western. In many cases the extra money might add little to the position of a prosperous selling carrier while its payment might be very injurious to the buyer. Nor could there be a balance when the selling carrier is disposing of all of its assets, as in the Marquette case; ${ }^{27}$ there the only benefit inured to Marquette's stockholders.

A curious thread running through the Board's decision in the Western-United case, which typifies its present attitude in matters of rate regulation, is that the high profits on the Denver-Los Angeles route are in fact quite justifiable and would not be decreased even if the Board were exercising strict control. The majority pointed out that rates are set for airlines systems as a whole, and not for individual routes, the result being that profits on some routes are higher than average while others are lower. This interpretation of airlines rate regulation is clearly valid but it presents its own answer to the purchase price problem. If future high profits on the Denver-Los Angeles route are to be allowed as an offset against low profits or actual losses on other routes, it is hardly proper for United

(C.C.A. 9th, 1945); Niagara Falls Power Co. v. Federal Power Commission, I37 F. 2d 787 (C.C.A. 2d, I943); Louisville Gas \& Electric Co. v. Federal Power Commission, 129 F. 2d I26 (C.C.A. 6th, 1942).

${ }^{25}$ Zoll, The Regulation of Motor Carrier Rates by the Interstate Commerce Commission, 8 I.C.C. Practitioners' Journal 45I, 453-66 (I94I).

26 "The public interest requires that a carrier refrain from reflecting figures in its accounts likely to create a false impression, and we do not believe that we should approve a transaction .... unless steps are to be taken to eliminate from the accounts any fictitious increase in assets represented by amounts paid for intangible property." Herrin Transportation Co.Purchase-Malbrough, 25 M.C.C. 710, 712 (1939). See Union Bus Lines-Purchase-Amberson, 5 M.C.C. 201 (1937).

${ }^{27}$ Acquisition of Marquette by T.W.A., 2 C.A.B. I (1940). 
to capitalize such expected profits in the purchase price and thus prevent for an indefinite time their use for the offsetting function.

The majority also pointed out that the Board's policy has been to approve rates which will allow the carrier, through particularly efficient management, to derive profits in excess of the stipulated rate of return. It was suggested that the excess profits on the Denver-Los Angeles route were justified as such a reward for good management. United, however, expects to make a profit on the route in I948 of $\$ \mathrm{r}, 650,000{ }^{28}$ If the maximum allowable rate base is assumed to be $\$ 2,250,000$, United's rate of return will be 73 per cent, a figure which suggests that the notion of incentive is being carried beyond the bounds of reason.

The Western-United decision involves a number of anomalous aspects which should embarrass the Board and which would have been avoided if Chairman Landis' view had been followed. The extra payment by United stands for a value placed on oligopolistic operating rights which are provided at no charge by the public. There is some justification in the Marquette case precedent for the recognition of such a value, but the Civil Aeronautics Act seems clearly to condemn it. ${ }^{29}$ Western Air Lines in I944 had strenuously and successfully argued before the Board that it was the proper carrier to operate the Denver-Los Angeles route $;^{30}$ now it was contending that a mistake had been made and that the public interest required that United take over. The admission would be most laudable except that Western was demanding a profit of $\$ 1,750,000$ on the mistake. United, on the other hand, was paying that amount for a route which the Board has now declared should in the public interest be operated by it. And lastly, the Board was approving as wise an expenditure of $\$ 3,750,000$ by United but at the same time saying that only $\$ 2,000,000$ of that sum was a "prudent investment."

A basic disagreement which obviously influenced the majority and dissenting opinions in the Western-United case concerns the functions and responsibilities of the Board in relation to route adjustments. The national airlines pattern was stabilized under the "grandfather clause" of the Civil Aeronautics Act ${ }^{3 \mathrm{x}}$ according to the routes being flown by the various carriers at the time of the statute. The use of that haphazard standard in the original stabilization of the route pattern, combined with the factor of constant improvements and changes in air transportation technology, have made it clear that many route adjustments must be made. Neither the legislative history of the statute nor its specific terms reveals the method by which these adjustments should be accomplished.

The majority contended that the Board's position should be primarily nega-

${ }^{28}$ Western-United, Acquisition of Air Carrier Property, Brief for Western Air Lines, at 13.

${ }_{29}$ "No certificate shall confer any proprietary, property, or exclusive right in the use of any air space, civil airway, landing area, or air-navigation facility." 49 U.S.C.A. $\$ 48 \mathrm{I}(\mathrm{j})$ (Supp., x946).

${ }^{30}$ Western Air Lines, Denver-Los Angeles Service, 6 C.A.B. $x 99$ (I944).

${ }^{3 x} 49$ U.S.C.A. $\$ 48 \mathrm{I}$ (e) (Supp., I946). 
tive-that it should rely on arrangements for route transfers voluntarily negotiated by individual carriers and that it should interfere only where the public interest is not being served. Economic forces and business motives must be allowed to function freely. However, economic forces will function in any framework, even in a framework delineated by a clear policy forbidding route transfers at prices exceeding the allowable investment rate base. Western Air Lines, for example, was motivated by its own general financial distress and by the knowledge that in the future it would probably operate the Denver-Los Angeles route at a loss; ${ }^{32}$ believing that the arrangement would be approved, it contracted to sell its certificate to United at a high price. The same economic motives presumably would make it good business for Western to abandon the route even if it knew that the Board would not allow a profit on the transaction.

A ruling that no exchange value would be allowed for airline operating rights would require that the Board take a more aggressive part in route adjustments. It would not be necessary for the Board to make wide use of its power to amend and suspend certificates, ${ }^{33}$ with a possible resulting demoralization of management planning; nor would the Board need to follow some master route plan as attempted by the Interstate Commerce Commission under the Transportation Act of $1920 .{ }^{34}$ There is no valid reason, however, why the Board should not use its control over subsidies and its power to issue new certificates to encourage needed route adjustments when ordinary economic motives fail to do so. The majority of the Board in the Western-United decision referred disapprovingly to such a technique as an unwarranted application of "pressures." The airlines, however, which have depended on public subsidies and monopolistic privileges for their very existence, are in no position to complain if those subsidies and privileges are withheld or dispensed so as to fill the public need for an efficient route pattern. The need for adjustments in the route pattern, in short, presents no valid reason for adopting a policy which in other respects involves grave dangers of an inflation in carrier investment.

The willingness of the Board to approve the Western-United transaction may be explained by the majority's fear of taking any action which would discourage initiative by the individual carriers. The Board should recognize, however, that the excessive profits over which the parties were bargaining are the result of its own inability to regulate, and that the public has a primary interest in the disposal of such funds. The Board can adequately fulfill its function only through a policy which, while encouraging the free play of entrepreneurial judgment, at the same time guards against an inflation of airline values and an unnecessary cost to the public.

32 Note 2 supra.

3349 U.S.C.A. $\$ 48 \mathrm{I}$ (h) (Supp., 1946). The Board showed its unwillingness to make "extensive" alterations in route systems under this power in Panagra Terminal Investigation, 4 C.A.B. 670 (1944).

${ }^{34} 4$ I Stat. 480 (I920), 49 U.S.C.A. $\$ 5(4)$ (1929). 